\title{
PREFACE
}

This book is designed to introduce the reader to some of the major debates in the field of gender studies. Although most of the debates that follow can be characterized as "mutually respectful conversations" (Stimpson, 1996, p. 70), several involve heated exchanges. But this is to be expected, for as Harvard University President Neil Rudenstine points out, "Discussion and debate are not purely intellectual processes. They involve emotion and conviction as well as reason and argument" $(1996$, p. 52).

Each of the eighteen controversies in this book offers two opposing points of view. Further, all of the debates were chosen with the conviction that the research on women that emerged in the 1970s transformed the field of psychology from a profession that, in Naomi Weisstein's words, had "nothing to say about women" (1968, p. 208) to one that now has a great deal to say. The new psychology of women, in turn, has served as a model for the study of men's roles. Where once only women seemed to have "gender" (Kimmel, 1995), the new psychology of men discusses gender, not as a biological given, but as a social construct capable of change (Levant \& Pollack, 1995).

I am aware that a few feminist scholars oppose using a debate format. As they point out, by participating in certain arguments-for example, whether or not the Holocaust occurred-one may be tacitly agreeing that the question is worth asking in the first place. The gender debates in this book, however, involve legitimate questions that have persisted over time. Meredith Kimball has provided a superb rationale for gender debates when she argues, "Feminist theories and politics will be richer and stronger, and ... each of us will provide a better criticism of our own work if we engage in practicing double visions" (1995, p. 11). My goal in editing this book of debates is to encourage a vigorous exchange of ideas among both scholars and other readers to gain a better understanding of gender issues.

There is, of course, nothing new in employing debates as a learning device. The Socratic method is some 2,400 years old. Nevertheless, the debate approach is especially appropriate at the present time. Charges of political correctness to the contrary, the following chapters demonstrate that there is no monolithic feminist viewpoint. Debates are no longer only between feminists and nonfeminists, nor are all the feminists female, as illustrated by several chapters.

The debate format also encourages critical thinking and engages the reader more actively. We live in a psychological society in which we are bombarded with information, much of it misleading, about gender issues. I believe that by being forced to evaluate conflicting viewpoints, readers will become more discriminating about psychological data, whether presented in the media or in the scientific literature. Lisa Elliot (1993), who used my previous book The Psychology of Women: Ongoing Debates (Walsh, 1987) in her classes, reported that the debate format empowered her students by enhancing their critical thinking skills. 


\section{WHO SHOULD READ THIS BOOK}

This book is intended for the general reader as well as for students and scholars. Many of the questions explored here are regularly debated in the popular media: "Is pornography harmful to women?" "Is one's sexual orientation determined by biology?" and "Do mothers harm their children when they work outside the home?" At the same time, the topics represent some of the most crucial issues in the field of gender studies. Although my own research area is the psychology of women, the contributors to this book represent many academic disciplines, including sociology, law, linguistics, management science, and psychiatry. Research on gender is constantly breaking new ground, and it depends on conflict and debate for the energy to grow. I hope that some scholars who read this book will want to expand (or refute) the arguments presented here and add to the published literature in the field, as many did after the publication of my earlier book.

\section{Choosing the Debate Topics}

After the publication of my first book of debates (Walsh, 1987), I was often asked how I selected the topics. I discovered the questions, in part, by drawing on my twenty years of teaching and consulting with colleagues in the field of gender studies. Equally valuable for this book were the new debate suggestions from a survey of 113 fellows of the American Psychological Association's Division of the Psychology of Women conducted by Yale University Press. I made my final choice of topics after additional research, including a systematic study of the literature and a careful analysis of textbooks in the field. In order to include as much new material as possible, I had to move beyond the published literature. Of the thirty-six chapters that follow, ten are original contributions and nineteen are revised versions of earlier publications.

Clearly not every controversy within the field found its way into this book. Space limitations forced me to choose from a number of possibilities. In making those difficult decisions, I used four criteria: (1) the controversy should deal with a significant question; (2) the controversy should be an ongoing one; (3) it should be relevant to some larger social issue, and (4) most important, the debate should involve strongly divergent points of view. The growing literature on diversity issues is impressive, and whenever possible, I made a special effort to bring this new multicultural research into my introductions to the debate topics.

\section{FEATURES OF THE BOOK}

I hope that this book will provide some understanding of how we arrive at what is defined as psychological knowledge. My goal as a scholar has always been to make material accessible. In order to place each question in context, I have written a brief introduction outlining the important issues. Because all the debates represent ongoing controversies, I have also included suggestions for further reading for each topic. In all, there are more than 1,800 recent bibliographical citations in this book. 
I do not claim that the two selections for each question always represent the definitive answers to a given issue. In some cases, both points of view will appear unsatisfactory. One of the underlying assumptions of this book is that research is a continuous dialogue in which dissent and difference of opinion are essential. As Virginia Woolf noted, "When a subject is highly controversial-and any question about sex is that-one cannot hope to tell the truth. One can only show how one came to hold whatever opinion one does hold. One can only give one's audience a chance of drawing their own conclusions as they observe the limitations, the prejudices, the idiosyncracies of the speaker" $(1929$, p. 4).

I hope, however, that the debate format provides some sense of the complexity of these issues: this would be the most valuable outcome. As historian C. Vann Woodward has pointed out: "Questions have to be asked before they can be even wrongly answered. Answers have to be ventured even before we are sure that they are addressed to the right questions. Errors have to be made before they can be corrected and contrary answers provoked. All of which leads to controversy, to be sure; but controversy is one of the ways we have of arriving at what we assign the dignity of truth" (1986, p. 33).

\section{REFERENCES}

Elliot, L. B. (1993). Using debates to teach the psychology of women. Teaching of Psychology, 20, 35-38.

Kimball, M. M. (1995). Feminist visions of gender similarities and differences. New York: Harrington Park Press.

Kimmel, M. S. (1996). Manhood in America: A cultural history. New York: Free Press.

Levant, R. F. \& Pollack, W. S. (1995). Introduction. In R. F. Levant \& W. S. Pollack (Eds.), A new psychology of men. New York: Basic Books.

Rudenstine, N. (1996). The uses of diversity. Harvard Magazine, (March-April), pp. 48-62.
Stimpson, C. R. (1996, Winter). Women's studies and its discontents. Dissent, pp. 67-75.

Walsh, M. R. (Ed.). (1987). The psychology of women: Ongoing debates. New Haven: Yale University Press.

Weisstein, N. (1968). "Kinder, Küche, Kirche" as scientific law: Psychology constructs the female. In $\mathbf{R}$. Morgan (Ed.), Sisterhood is powerful: An anthology of writings from the women's liberation movement (pp. 205-220). New York: Vintage Books.

Woodward, C. V. (1986, Feb. 3). Between Little Rock and a hard place. New Republic, pp. 29-33.

Woolf, V. (1929). A room of one's own. New York: Harcourt, Brace, \& World, 1957. 